\title{
Morphometric Description of Thoracic Vertebral Pedicles in Adult Malawian Cadavers and Implications for Transpedicular Spine Fixation
}

\author{
Descripción Morfometrica de los Pedículos Vertebrales Torácicos en Cadáveres de \\ Malawi Adultos e Implicaciones para la Fijación Transpedicular de la Columna
}

\author{
A. Mwakikunga ${ }^{1,3}$; A. Manjatika ${ }^{1,3}$ \& P. Mazengenya ${ }^{2,3,4}$
}

MWAKIKUNGA, A.; MANJATIKA, A. \& MAZENGENYA, P. Morphometric description of thoracic vertebral pedicles in adult Malawian cadavers and implications for transpedicular spine fixation. Int. J. Morphol., 39(6):1575-1580, 2021.

SUMMARY: Thoracic pedicles are important during the surgical repair of the thoracic spine deformities. Individuals show considerable differences in the asymmetric dimensions of the thoracic pedicles across populations. The purpose of this study was to determine the thoracic pedicle size and angle in adult Malawian cadavers and to suggest the clinical implications associated particularly the transpedicular fixation of spinal deformities. Adult thoracic vertebra from undetermined sex specimens ( $\mathrm{n}=227)$ from the skeletal collection in the Anatomy Division, Biomedical Sciences Department, College of Medicine, University of Malawi were measured to assess the pedicle width, pedicle height, chord length, transverse diameter, interpedicular distance, transverse and sagittal pedicle angles. The mean pedicle width was $4.71 \pm 1.83 \mathrm{~mm}$ (left side) and $4.82 \pm 1.77 \mathrm{~mm}$ (right side) and the mean pedicle height was $12.63 \pm 2.61 \mathrm{~mm}$ (left side) and $12.60 \pm 2.54 \mathrm{~mm}$ (right side). The mean transverse pedicle angle was $12.22 \pm 2.30$ degrees (left side) and $12.46 \pm 2.34$ degrees (right side). The mean sagittal pedicle angle was $9.24 \pm 2.67$ degrees (left side) and $9.40 \pm 2.76$ degrees (right side). The mean interpedicular distance was $16.67 \pm 2.23 \mathrm{~mm}$. Our sample population generally showed smaller thoracic pedicle dimensions than those reported in other populations. Prior knowledge of the variations regarding the thoracic pedicle dimensions is vital for the determination of the pedicle screw size and design. Most importantly the information helps surgeons during preoperative planning of the transpedicular thoracic spine fixation and radiological interpretation.

KEY WORDS: Thoracic vertebra; Pedicle dimensions; Pedicle screws; Spinal fixation, Malawians.

\section{INTRODUCTION}

The use of pedicle screws during posterior spinal fixation has become increasingly common worldwide (Chadha et al., 2003; Yu et al., 2014). Pedicle screws offer rigid segmental fixation after decompression and arthrodesis for various disorders of the spine, including scoliosis, spondylolisthesis, fractures, tumour and iatrogenic or degenerative instability (Patil \& Bhuiyan, 2009). Many pedicle screw systems have been developed and they all involve the insertion of screws through the pedicle (from the posterior aspect) into the vertebral body (Morales-Avalos et al., 2014). The screws enable various devices (plates, rods or wires) to be applied to the spine for the purpose of immobilisation or fixation (Morales-Avalos et al.). The use of pedicle screws in the thoracic spine poses a great challenge because the thoracic vertebral pedicles are smaller in size and more variable when compared to the standard lumbar vertebral pedicles (Patil \& Bhuiyan; Shetty et al., 2011).

Pedicles are the strongest parts of the vertebra and they are seldom impaired even during vertebral osteoporosis (McLain et al., 2002; Shetty et al.). The information about the pedicle morphology particularly the length and width dimensions are important as they can be used in the selection and design of suitably sized pedicle screws for posterior transpedicular spinal fixation (Avuthu et al., 2014). For a safe passage through the pedicle, fixation screws require a minimum of $0.5 \mathrm{~mm}$ clearance on each side to avoid perforation of the pedicle cortex (Gokcen et al., 2018).

\footnotetext{
${ }^{1}$ School of Life Sciences, Department of Biomedical Sciences, Anatomy Division, Kamuzu University of Health Sciences (Formerly College of Medicine, University of Malawi), Blantyre, Malawi.

${ }^{2}$ College of Medicine, Ajman University, Ajman, United Arab Emirates.

${ }^{3}$ School of Anatomical Sciences, University of the Witwatersrand, Parktown, Johannesburg, South Africa.

${ }^{4}$ Center of Medical and Bio-allied Health Sciences Research, Ajman University, Ajman, United Arab Emirates.
} 
Several studies have investigated the morphology of vertebral pedicles using differing measurement techniques such as direct measurement on dry bones or cadavers, measurement on plain radiographs and or computerised tomographic scans (Acharya et al., 2010; Avuthu et al.; Yu et al.). Evidence has shown that no significant difference exists between data obtained from computed tomographic scans and direct cadaveric measurements (Kim et al., 1994; Maaly et al., 2010). However, significant population and ethnic differences in the vertebral pedicle morphometry have been reported (Datir \& Mitra, 2004; Tan et al., 2004; Lehman Jr. et al., 2014), hence there is a need for tailor-made vertebral pedicle screws for specific populations to ensure successful posterior transpedicular fixation. There are no known studies in the literature on the thoracic vertebral pedicles in Southern African populations including Malawians. Therefore, the present study was conducted to describe the morphometric characteristics of the thoracic vertebral pedicles in adult Malawians in order to inform the design and size of the pedicle fixation screws to be safely used in adult Malawians during the surgical repair of spinal disorders.

\section{MATERIAL AND METHOD}

The current study was conducted in accordance with the Government of Malawi, Anatomy Act No. 14 of 1990 and was approved by the University of Malawi's College of Medicine Research and Ethics Committee (COMREC) with a clearance number P02/10/872. The study was conducted on adult human cadaveric dry thoracic vertebrae obtained from the Anatomy Division Bone Collection housed in the Biomedical Sciences Department, College of Medicine, University of Malawi. The study sample included only the vertebra prepared from adult Malawian cadavers. A total of 227 undamaged and pathology free thoracic vertebrae obtained from individuals aged between 21-82 years were selected for the study. The typical osteological features of the thoracic vertebrae were utilised during the correct classification of the vertebrae.

Measurements. The following parameters were measured (Fig. 1A-E) as described previously (Zindrick et al., 1987; Weinstein et al., 1992).

A. Pedicle height (sagittal diameter) at the isthmus of the pedicle: This vertical distance between superior and inferior margin of the pedicle at its midpoint was measured using a Vernier calliper.

B. Pedicle width (transverse diameter) at the isthmus of the pedicle: This distance was measured between medial and lateral surfaces of the pedicle at its midpoint, at the right angle to the long axis of the pedicle. The pedicle axis was defined as a line perpendicular to and bisecting the narrowest diameter of the pedicle measured using a Vernier calliper.
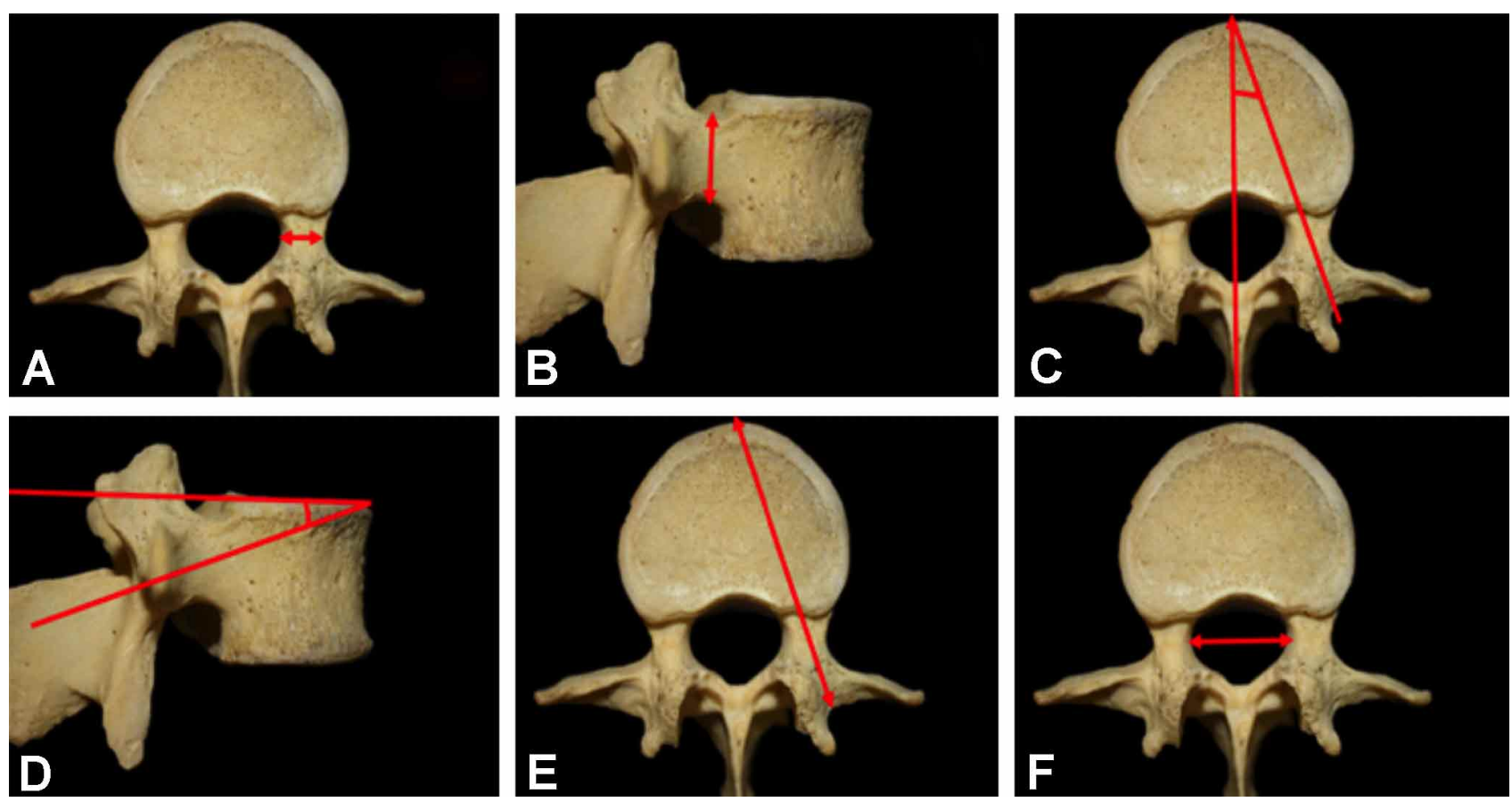

Fig. 1. Photographs showing the various measurements that were taken on the vertebra. A. Pedicle width, B. Pedicle height, C. Transverse angle, D. Sagittal angle, E. Chord length and F. Interpedicular distance. 
C. Sagittal pedicle angle: This angle was measured between a line passing through the pedicle axis and superior vertebral margin in the sagittal plane measured using a goniometer.

D. Transverse pedicle angle: this angle was measured between the midsagittal plane (line) and the plane (line) bisecting the pedicle measured using a goniometer.

E. Chord length (screw path length): This distance was measured from the most posterior aspect of the lamina cortex to the anterior cortex of the vertebral body along the pedicle axis measured using a Vernier calliper.

F.Interpedicular distance: this is the distance between the medial surfaces of the right and left vertebral pedicles taken at the level of the isthmus using a Vernier calliper.

Data analysis. The data were managed in Microsoft Excel (Microsoft Corporation) and analysed using SPSS ${ }^{\circledR}$ version 21. A p-value $<0.05$ was considered significant at the $95 \%$ confidence interval. Quantitative data were presented using descriptive statistics (mean, range and standard deviation). Univariate analyses of continuous data were performed using paired sample student t-test to compare mean pedicle dimensions of the right and left sides.

\section{RESULTS}

In the present study, there was a significant difference in the mean pedicle width between the right (mean: $4.819 \pm 1.7744)$ and left (mean:4.707 \pm 1.840 ) pedicles $(\mathrm{p}<0.001)$ with the mean on the right side being larger than on the left side (Table I and Fig. 2). Pedicle width on both sides ranged from $2.0-11.0 \mathrm{~mm}$. The mean pedicle height on the right and left sides was $12.46 \pm 2.543$ and $12.63 \pm 2.605$ respectively but there was no statistically significant difference between the sides $(\mathrm{p} \leq 0.05)$ (Table I and Fig. 2).

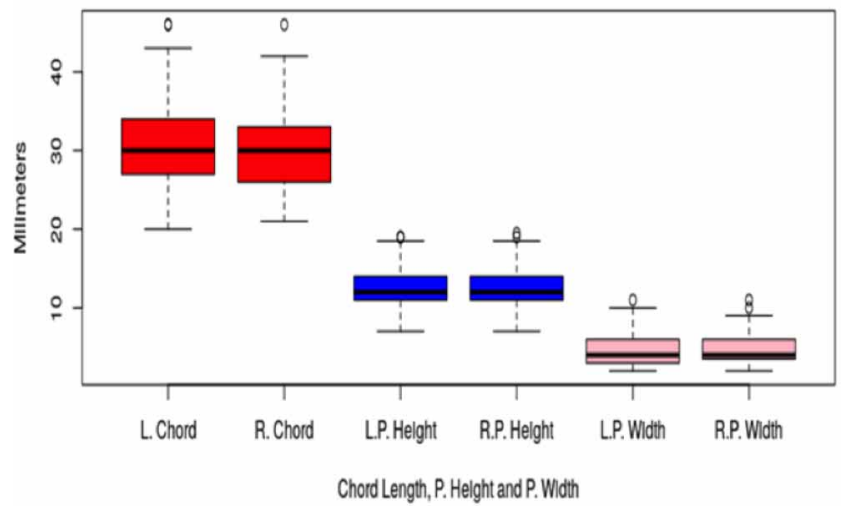

Fig. 2. Trends in relationships between left and right chord length, pedicle height and pedicle width. Shows trends in relationships between left (L) and right (R) chord length (red), pedicle height (blue) and pedicle width (purple). There is significant difference in the chord length and pedicle width $(\mathrm{p} \leq 0.05)$; no significant difference in the pedicle height between left and right (p?0.05).

The mean chord length of the thoracic vertebra on both the right and left sides was $30.08 \pm 4.734 \mathrm{~mm}$ and 30.40 $\pm 4.899 \mathrm{~mm}$ respectively. It ranged from $20.00-46.00$ $\mathrm{mm}$ in length. The mean chord length on the left side was significantly larger than that on the right side $(\mathrm{p} \leq 0.05)$ (Table I and Fig. 2). The Interpedicular distance ranged from $12.00-23.00 \mathrm{~mm}$ with a mean of $16.67 \pm 2.22 \mathrm{~mm}$ (Table I).

As presented in Table I and Figure 3, there was a statistically significant difference in the mean transverse pedicle angles between left and right side $(\mathrm{p}<0.001)$ ranging from 8 - 20 degrees on the left and 9 - 20 degrees on the right, with a larger mean on the right side. There was also statistically significant difference in the mean sagittal pedicle angles between left and right side $(\mathrm{p} \leq 0.05)$ ranging from 4.00 - 18.00 degrees on both sides (Table I and Fig. 3).

Table I. A summary of descriptive analyses and comparison of means of the left and right thoracic pedicle width, height, chord length, interpedicular distance and the sagittal and transverse pedicle angles.

\begin{tabular}{|c|c|c|c|c|c|c|c|c|c|c|c|}
\hline \multirow[t]{2}{*}{ Variable } & \multicolumn{2}{|c|}{ Width(mm) } & \multicolumn{2}{|c|}{ Height (mm) } & \multicolumn{2}{|c|}{ Chord Length (mm) } & \multicolumn{2}{|c|}{$\begin{array}{l}\text { Sagittal angle } \\
\text { (degrees) }\end{array}$} & \multicolumn{2}{|c|}{$\begin{array}{c}\text { Transverse angle } \\
\text { (degrees) }\end{array}$} & \multirow[t]{2}{*}{$\begin{array}{l}\text { Interpedicular } \\
\text { distance }(\mathrm{mm})\end{array}$} \\
\hline & Left & Right & Left & Right & Left & Right & Left & Right & Left & Right & \\
\hline Mean & 4.707 & 4.819 & 12.63 & 12.46 & 30.40 & 30.08 & 9.24 & 9.4 & 12.22 & 12.46 & 16.67 \\
\hline Std Deviation & 1.840 & 1.774 & 2.605 & 2.543 & 4.899 & 4.734 & 2.665 & 2.762 & 2.301 & 2.341 & 2.225 \\
\hline Std Error & 0.122 & 0.118 & 0.173 & 0.169 & 0.325 & 0.314 & 0.117 & 0.183 & 0.153 & 0.155 & 0.148 \\
\hline Mode & 4 & 4 & 12 & 12 & 27 & 27 & 8 & 10 & 11 & 11 & 15 \\
\hline Minimum & 2 & 2 & 7 & 7 & 20 & 21 & 4 & 4 & 8 & 9 & 12 \\
\hline Maximum & 11 & 11 & 19 & 19.5 & 46 & 46 & 14 & 18 & 20 & 20 & 23 \\
\hline P-value & \multicolumn{2}{|c|}{$0.001 *$} & \multicolumn{2}{|c|}{0.434} & \multicolumn{2}{|c|}{$0.001 *$} & & & \multicolumn{2}{|c|}{$0.001 *$} & \\
\hline Remarks & $\mathrm{S}$ & & NS & & $\mathrm{S}$ & & $\mathrm{S}$ & & $\mathrm{S}$ & & \\
\hline
\end{tabular}

$\mathrm{n}=227, *=$ Significant difference $(\mathrm{S}), \mathrm{NS}=$ No significant difference. 


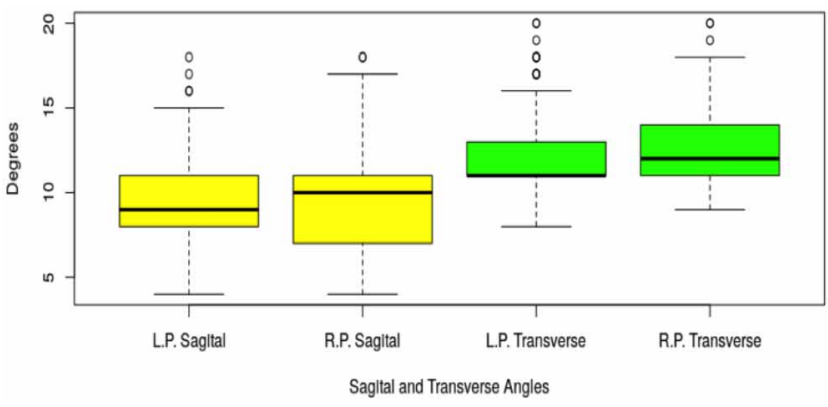

Fig. 3. Trends of relationships between left and right pedicle sagittal angle and left and right pedicle transverse angles. Shows trends of relationships between left and right pedicle sagittal angle (yellow) and left and right pedicle transverse angles (green). In both pedicle sagittal and transverse angles there is significant difference between left and right sides $(\mathrm{p} \leq 0.05)$.

\section{DISCUSSION}

The current study examined the dimensions of the thoracic vertebral pedicles of the Malawian population and their implications in transpedicular screw fixations during the surgical fixation of the vertebral spine. Numerous studies reported on the variations of the dimensions of the vertebral pedicles in various populations, particularly at the thinnest point on the isthmus (Panjabi et al., 1991; Weinstein et al.; Patil \& Bhuiyan; Singh et al., 2011). These dimensional variations are population specific and may be attributed to genetic, environmental and regional differences. Such variations have profound implications on the diameter of the screws to be used during spinal fixation. During spinal fixation, the pedicle screw must avoid damaging the cortex of the pedicle in order to preserve the spinal cord (on the medial surface) and spinal nerve roots and ganglia (on both the superior and inferior surfaces) (Patil \& Bhuiyan; Hotchkiss et al., 2016).

The mean pedicle width of the thoracic vertebra reported in the present study is consistent with the findings from an Indian population (Singh et al.) but smaller than the one reported in the American population (Panjabi et al.). The current observation of the variant mean pedicle width supports population specificity on this dimension. During transpedicular spine fixation, the pedicle width is important as it determines the diameter of the screw that can be accommodated safely in a pedicle without breaching its medial and lateral cortices (Weinstein et al.; Patil \& Bhuiyan).

The mean pedicle height in the present study corresponds with that reported in a cadaveric study in the Indian population (Datir \& Mitra) and a radiographic study in the American population (Zindrick et al.). In addition, the mean pedicle height of Malawian thoracic vertebra is comparably higher than that observed in the dry bone study in the Indian population (Patil \& Bhuiyan). Clinically, the pedicle height like the width dimension influences pedicle screw selection due to the clearance it gives to the surgeon at the time of the pedicle aiming (Patil \& Bhuiyan). In most studies, it has been established that the pedicle height is always greater than the pedicle width, and the present study corroborates this finding (Berry et al., 1987; Lien et al., 2007; Pai et al., 2010).

The mean transverse pedicle angle in the pre-sent study is similar to that reported in other populations (Zindrick et al.; Pai et al.; Singh et al.). The knowledge of transverse pedicle angle is important during screw placement as any inadvertent medial perfora-tion due to wrong placement of the pedicle screw can put the spinal cord at risk or cause vascular injury (Patil \& Bhuiyan; Hotchkiss et al.). The mean sagittal pedicle angle in the present study agrees with the findings of a study done on the Indian population (Datir \& Mitra). But the mean sagittal pedicle angle in the present study is generally smaller than those of Taiwanese and American populations (Zindrick et al.; Lien et al.; Singh et $a l$.) suggesting that there are differences in the morphometric dimensions among different ethnic groups. These variations on the mean sagittal pedicle angle could not only bebecauseof geographical, nutritional and genetic factors, but also due to different techniques and methodologies used to assess the angle. Sagittal pedicle angle is important in accurate screw placement as inferior migration of the screw may re-sult in injury to the spinal nerve roots.

The present study observed that the mean chord length of the adult Malawians is lower than that reported in Indian dry bones (Patil \& Bhuiyan) and American cadaveric samples (McLain et al.). These variations further indicate population specificity (Table II). In addition, it is demonstrated that pedicle dimensions in Koreans, Chinese Singaporeans and Japanese are generally smaller than in populations from the western countries (Tan et al.; Nojiri et al., 2005; Lehman Jr. et al.). On the other hand, significant pedicle size differences between Indian and Caucasian populations are also reported (Chadha et al.; Acharya et al.). The mean chord length in the present study is, however, similar to the mean chord length reported in a Singaporean population (Tan et al.). The chord length variations per vertebral region indicated for the design of screws that avoid perforating the anterior cortex of the vertebra body, which may lead to injuries of the vital organs and major blood vessels such as the descending aorta (Lehman Jr. et al.). The mean interpedicular distance in the present study is smaller than that reported in the Indian (Datir \& Mitra) and French 


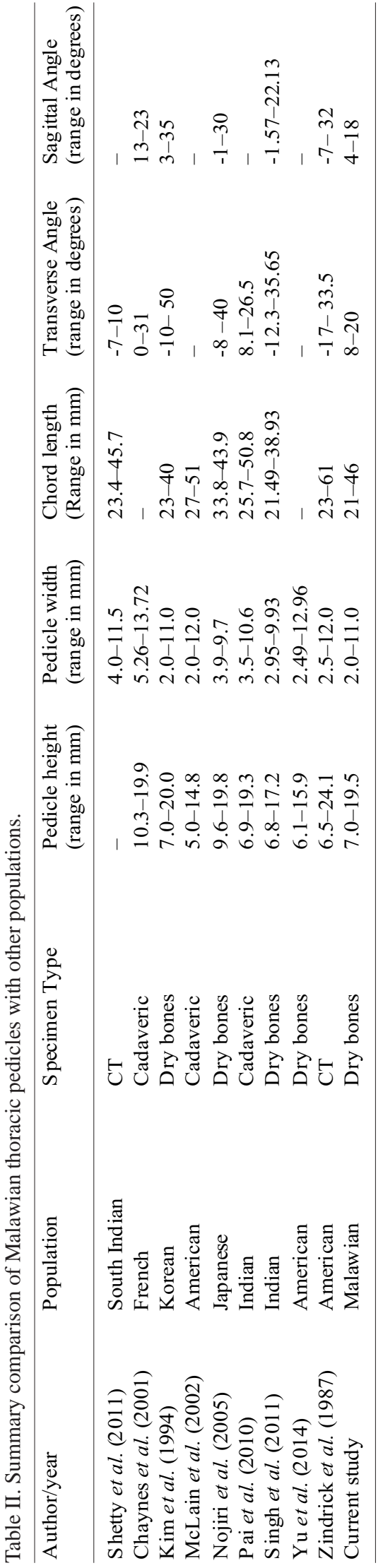

(Chaynes et al., 2001) populations. The interpedicular distance determines the design of the inter-rode support system and also directs the screw path to avoid damage to spinal nerve roots, dura matter and spinal cord (Patil \& Bhuiyan). It is therefore important to consider population variations during the designing of pedicle screws to minimize iatrogenic injuries (Tan et al.; Nojiri et al.; Lehman Jr. et al.).

In conclusion, the current study population showed smaller pedicle dimensions when compared to other populations. The varying pedicle dimensions are population specific. Surgeons should, therefore, take this into consideration during preoperative planning and when choosing transpedicular screws for use during thoracic spine fixation in adult Malawians.

\section{ACKNOWLEDGMENTS}

We thank the staff of the School of Anatomical Sciences, University of the Witwatersrand and staff of School of Life Sciences, Anatomy Division, Kamuzu University of Health Sciencesfor their support. This work was funded through a postdoctoral fellowship to Dr Anthony Mwakikunga through Professor Lynne Schepartz.

\footnotetext{
WAKIKUNGA, A.; MANJATIKA, A. \& MAZENGENYA, P. Descripción morfométrica de los pedículos vertebrales torácicos en cadáveres adultos de Malawi e implicaciones para la fijación transpedicular de la columna. Int. J. Morphol., 39(6):1575-1580, 2021.
}

RESUMEN: Los pedículos de las vértebras torácicas son importantes durante la reparación quirúrgica de las deformidades de la columna torácica. Los individuos muestran diferencias considerables en las dimensiones asimétricas de las vértebras torácicas entre poblaciones. El propósito de este estudio fue determinar el tamaño y el ángulo los pedículos de las vértebras torácicas en cadáveres de Malawi adultos y sugerir las implicaciones clínicas asociadas a la fijación transpedicular de las deformidades espinales. Se midieron 227 vértebras torácicas de muestras de individuos de sexo indeterminado de la colección esquelética en la División de Anatomía, Departamento de Ciencias Biomédicas, Facultad de Medicina, Universidad de Malawi para evaluar el ancho del pedículo, la altura del pedículo, la longitud, el diámetro transversal, distancia interpedicular y ángulos pediculares transversales y sagitales. El ancho medio del pedículo fue de 4,71 $\pm 1,83 \mathrm{~mm}$ (lado izquierdo) y 4,82 $\pm 1,77 \mathrm{~mm}$ (lado derecho) y la altura media del pedículo fue de 12,63 $\pm 2,61 \mathrm{~mm}$ (lado izquierdo) y $12,60 \pm 2,54 \mathrm{~mm}$ (lado derecho). El ángulo pedicular transverso medio fue de 12,22 \pm 2,3 grados (lado izquierdo) y 12,46 $\pm 2,34$ grados (lado derecho). El ángulo pedicular sagital medio fue de 9,24 $\pm 2,67$ grados (lado izquierdo) y 9,40 $\pm 2,76$ grados (lado derecho). La distancia interpedicular media fue de 16,67 $\pm 2,23 \mathrm{~mm}$. La población de esta muestra mostró dimensiones de los pedículos de las vértebras torácicas generalmente más pequeñas que las informadas en otras poblaciones. El conocimiento previo de las variaciones con respecto a las dimensiones de los pedículos de las vértebras torácicas es vital para la determinación del tamaño y diseño del tornillo pedicular. Lo más importante es que la información ayuda a los cirujanos durante la planificación preoperatoria para la fijación transpedicular de la columna torácica y su interpretación radiológica.

PALABRAS CLAVE: Vértebra torácica; Dimensiones del pedículo; Tornillos pediculares; Fijación espinal; Malauíes. 


\section{REFERENCES}

Acharya, S.; Dorje, T. \& Srivastava, A. Lower dorsal and lumbar pedicle morphometry in Indian population: a study of four hundred fifty vertebrae. Spine (Phila Pa 1976), 35(10):E378-84, 2010.

Avuthu, S.; Salian V, P. R.; Kotian, P. \& Shetty B, S. K. Computed tomographic morphometry of thoracic and lumbar pedicles in south Indian population. Asian J. Pharm. Health Sci, 4(2):996-1000, 2014.

Berry, J. L.; Moran, J. M.; Berg, W. S. \& Steffee, A. D. A morphometric study of human lumbar and selected thoracic vertebrae. Spine (Phila Pa 1976), 12(4):362-7, 1987.

Chadha, M.; Balain, B.; Maini, L. \& Dhaon, B. K. Pedicle morphology of the lower thoracic, lumbar, and S1 vertebrae: an Indian perspective. Spine (Phila Pa 1976), 28(8):744-9, 2003.

Chaynes, P.; Sol, J. C.; Vaysse, P.; Bécue, J. \& Lagarrigue, J. Vertebral pedicle anatomy in relation to pedicle screw fixation: a cadaver study. Surg. Radiol. Anat., 23(2):85-90, 2001.

Datir, S. P. \& Mitra, S. R. Morphometric study of the thoracic vertebral pedicle in an Indian population. Spine (Phila Pa 1976), 29(11):117481, 2004.

Gokcen, H. B.; Erdogan, S.; Ozturk, S.; Gumussuyu, G.; Bayram, I. \& Ozturk, C. Sagittal orientation and uniform entry for thoracic pedicle screw placement with free-hand technique: A retrospective study on 382 pedicle screws. Int. J. Surg., 51:83-8, 2018.

Hotchkiss, W. R.; Schwend, R. M.; Bosch, P. P.; Edgar, H. J. H. \& Young, B. N. Defining the differences in transverse plane trajectories for thoracic pedicle screw insertion: anatomic versus medial. Spine Deform., 4(1):22-6, 2016

Kim, N. H.; Lee, H. M., Chung, I. H.; Kim, H. J. \& Kim, S. J. Morphometric study of the pedicles of thoracic and lumbar vertebrae in Koreans. Spine (Phila Pa 1976), 19(12):1390-4, 1994.

Lehman Jr., R. A.; Kang, D. G.; Lenke, L. G.; Gaume, R. E. \& Paik, H. The ventral lamina and superior facet rule: a morphometric analysis for an ideal thoracic pedicle screw starting point. Spine J., 14(1):137-44, 2014.

Lien, S. B.; Liou, N. H. \& Wu, S. S. Analysis of anatomic morphometry of the pedicles and the safe zone for through-pedicle procedures in the thoracic and lumbar spine. Eur. Spine J., 16(8):1215-22, 2007.

Maaly, M. A.; Saad, A. \& Houlel, M. E. E. Morphological measurements of lumbar pedicles in Egyptian population using computerized tomography and cadaver direct caliber measurements. Egypt. J. Radiol. Nucl. Med., 41(4):475-81, 2010.

McLain, R. F.; Ferrara, L. \& Kabins, M. Pedicle morphometry in the upper thoracic spine: limits to safe screw placement in older patients. Spine (Phila Pa 1976), 27(22):2467-71, 2002.

Morales-Avalos, R.; Leyva-Villegas, J.; Sánchez-Mejorada, G.; CárdenasSerna, M.; Vílchez-Cavazos, F.; De León, Á. M. P.; Elizondo-Riojas, G.; Martínez-García, J.; De La Garza-Castro, O.; Elizondo-Omaña, R.; et al. Age- and gender-related variations in morphometric characteristics of thoracic spine pedicle: A study of 4,800 pedicles. Clin. Anat., 27(3):441-50, 2014

Nojiri, K.; Matsumoto, M.; Chiba, K. \& Toyama, Y. Morphometric analysis of the thoracic and lumbar spine in Japanese on the use of pedicle screws. Surg. Radiol. Anat., 27(2):123-8, 2005.

Pai, B. S.; Gangadhara; Nirmala, S.; Muralimohan, S. \& Varsha, S. M. Morphometric analysis of the thoracic pedicle: an anatomicoradiological study. Neurol. India, 58(2):253-8, 2010.

Panjabi, M. M.; Takata, K.; Goel, V.; Federico, D.; Oxland, T.; Duranceau, J. \& Krag, M. Thoracic human vertebrae. Quantitative three-dimensional anatomy. Spine (Phila Pa 1976), 16(8):888-901, 1991.

Patil, D. K. \& Bhuiyan, P. S. A morphometric study of the Pedicles of dry human typical lumbar vertebrae. Indian J. Med. Res., 3(3):428-33, 2009.

Shetty, A.; Avadhani, R.; Mahesha, B. \& Shantaram, M. Pedicle morphometry: A radiological assessment using computerized tomographic (CT) scan. Int. J. Basic. Appl. Med. Sci., 1(1):23-5, 2011.
Singh, R.; Srivastva, S. K.; Prasath, C. S. V.; Rohilla, R. K.; Siwach, R. \& Magu, N. K. Morphometric measurements of cadaveric thoracic spine in Indian population and its clinical applications. Asian Spine J., 5(1):2034, 2011.

Tan, S. H.; Teo, E. C. \& Chua, H. C. Quantitative three-dimensional anatomy of cervical, thoracic and lumbar vertebrae of Chinese Singaporeans. Eur. Spine J., 13(2):137-46, 2004.

Weinstein, J. N.; Rydevik, B. L. \& Rauschning, W. Anatomic and technical considerations of pedicle screw fixation. Clin. Orthop. Relat. Res., (284):34-46, 1992.

Yu, C. C.; Bajwa, N. S.; Toy, J. O.; Ahn, U. M. \& Ahn, N. U. Pedicle morphometry of upper thoracic vertebrae: an anatomic study of 503 cadaveric specimens. Spine (Phila Pa 1976), 39(20):E1201-9, 2014.

Zindrick, M. R.; Wiltse, L. L.; Doornik, A.; Widell, E. H.; Knight, G. W.; Patwardhan, A. G.; Thomas, J. C.; Rothman, S. L. \& Fields, B. Analysis of the morphometric characteristics of the thoracic and lumbar pedicles. Spine (Phila Pa 1976), 12(2):160-6, 1987.

\author{
Corresponding author: \\ Dr Pedzisai Mazengenya \\ College of Medicine \\ Ajman University \\ Ajman \\ UNITED ARAB EMIRATES
}

E-mail: p.mazengenya@ajman.ac.ae

Received: 02-06-2021

Accepted: 24-07-2021 